\title{
Relationship Between Learned Resourcefulness and Academic Procrastination in Students Studying in Sports Departments
}

\author{
Barış Karaoğlu ${ }^{1} \&$ İlimdar Yalçın ${ }^{1}$ \\ ${ }^{1}$ School of Physical Education and Sports, Bingol University, Bingol, Turkey \\ Correspondence: Barış Karaoğlu, School of Physical Education and Sports, Bingol University, 12000, Bingol, \\ Turkey. E-mail: justified13@hotmail.com
}

Received: March 11, 2020

Accepted: April 21, $2020 \quad$ Online Published: June 21, 2020

doi:10.5539/ies.v13n7p88

URL: https://doi.org/10.5539/ies.v13n7p88

\begin{abstract}
The aim of this study was to investigate the relationship between the learned resourcefulness levels and academic procrastination of students studying in sports departments. A total of 372 students who studied in Bingöl University at School of Physical Education and Sports participated in the study as volunteers. In the study, the personal information form, learned resourcefulness scale, and academic procrastination scale were used as data collection tools. In the analysis of the obtained data, Pearson Correlation and Linear Regression analysis were applied by using the SPSS package program. According to the research findings, it was determined that there was a positive relationship between the learned resourcefulness level and the level of academic procrastination, and the learned resourcefulness predicted the academic procrastination level by $8 \%$. As a result; it was concluded that there was a low level and a positive correlation between learned resourcefulness level and academic procrastination, and learned resourcefulness power affects academic procrastination. In this context, it was thought that coping with the difficulties faced by students was important in both achieving their academic goals in school life and maintaining their psychological health.
\end{abstract}

Keywords: students, sports department, learned resourcefulness, academic procrastination

\section{Introduction}

The concept of learned resourcefulness which was used as an individual factor to explain human behavior was first introduced by Meichenbaum in 1977. In 1980, the concept was included in the literature with a detailed explanation of Rosenbaum's concept of learned resourcefulness. "Learned resourcefulness" defined by Rosenbaum as the total of behavior repertoire and abilities to organize cognitive, emotional, and sensory internal events that prevent the individual from reaching the target behavior while performing daily life activities is not only a belief but also abilities and self-control behavior (Rosenbaum, 1983). Learned resourcefulness was formulated by Rosenbaum (1990) as the conceptual model of self-control and it is a concept that can affect a wide range of behavioral outcomes, involves coping with various stressful situations successfully such as chronic diseases, and emphasizes individual differences in self-control skills.

It was observed that if the learned resourcefulness which is defined as a repertory of behavior and abilities used by individuals to reach their target behaviors, to prevent the disturbing effect of internal life events such as emotion, pain or unwanted thought is at high levels in individuals, they are successful in keeping stressful situations under control. Since individuals learn many basic concepts reflecting their behaviors, beliefs, and communication styles from their families, the domestic psychological relationship pattern has a significant effect on young people's development of learned resourcefulness personality features (Vural, 2004). In the development of this concept, it can be observed that Rosenbaum (1983) was influenced by prior behavioral studies and based his theory on these studies. The concept is mainly based on the logic of self-help instead of asking for help or getting help from others in situations which the individuals experience difficulties (Zauszniewski \& Martin, 1999). Rosenbaum (1983) states that learned resourcefulness is gained as a result of interaction with the environment throughout life and the behaviors defined as learned resourcefulness are learned within the environment in which the individual grows.

Studies indicate that people with high levels of learned resourcefulness can struggle with preventive stress and problems more effectively. According to the results of these studies, individuals with high success levels are academically strong individuals. These individuals set goals to achieve them, use effective problem-solving strategies, think positively despite academic expectations and obstacles, trust information from social and 
non-social sources (such as libraries), take notes, create their environment in a way that makes learning easier, and abide by the results of their actions (punishments or rewards) (Dönmez \& Genç, 2006).

The personal characteristics affect students' success tendencies (Turan, Karaoğlu, \& Pepe, 2017). Each individual has decisions to take throughout their lives, responsibilities to undertake, problems waiting to be solved at the center of daily life, and duties to be fulfilled (Koç, 2018). However, many individuals delay their activities, in other words, procrastination them due to various reasons. Therefore, many individuals experience long-term stress and anxiety depending on their procrastinating behavior, however, they can still procrastination their activities with the thought of "not doing what can be done today by delaying tomorrow" (Akbay, 2009). The concept of procrastination, based on the word "procrastinates", which means postponing in Latin (Balk1s, 2006), is defined as the delay of the decisions to be taken despite the opportunity, and the delay of the decisions to be taken despite the opportunity by Ferrari (1991). Kandemir (2010) defines procrastination as not doing a behavior or task voluntarily by ignoring other options even though the individuals know that their selection would have negative effects. Academic procrastination is defined as a tendency to continuously or regularly delay the academic duties individuals undertake and consequently, to experience anxiety. Academic procrastination tendency is defined as doing homework, preparing for exams or carrying out projects that will be submitted at the end of the semester at the last minute.

The studies in the literature indicate that the academic procrastination behavior is related to ineffective learning strategies (Piza et al., 2019), low grade point average, boredom, experiencing difficulty in doing homework, unplanned study habits (Senécal, Koestner, \& Vallerand, 1995) unrealistic excuses, anxiety, fear of failure, depression, irrational thinking, low self-esteem (Ferrari, \& Beck, 1999) low self-efficacy, low self-control, identity moratorium status (Turan, Karaoğlu, \& Pepe, 2017) and inability to procrastination satisfaction (Newsome, Helou, \& Crismon, 2019).

When the literature is examined, it was observed that there were many studies on learned resourcefulness (Kennett, Quinn-Nilas, \& Carty, 2020; Bilgili \& Tekin, 2019; Baydoğan \& Dağ, 2008) and academic procrastination (Amani \& Arbabi, 2020; Muliani, Imam, \& Dendiawan 2020; Dike \& Emmanuel, 2019; Johnson, Green, \& Kluever, 2000).

When we evaluate the above-mentioned information as a whole, it can be observed that the concepts of learned resourcefulness and academic procrastination can be effective in different dimensions, levels, and areas of life. However, there were not any studies in the literature in which the variables of learned resourcefulness and academic procrastination tendencies were examined together on university students who were studied in the department of physical education and sports. In this respect, this study is considered to contribute to the field of physical education and sports and bring a different perspective to the field. In this context, the present research aims to examine the relationship between learned resourcefulness levels and academic procrastination tendencies of the school of physical education and sports students.

\section{Method}

The method section describes in detail how the study was conducted, including conceptual and operational definitions of the variables used in the study.

\subsection{Research Model}

In the research, a method for a descriptive survey and relational survey are used which aim to reveal the current situation. Descriptive survey models are the research approaches that aim to describe a situation in the past or an existing situation. The event, individual or object that is the subject of the research is tried to be defined in its own conditions and as it is and no effort is made to change or influence them in any way. Relational survey models are research models that aim to determine the presence and/or degree of the co-variation between two or more variables (Karasar, 2004).

\subsection{Participants}

A total of 372 students who studied in physical education and sports teaching, coaching education and sport management departments in the School of Physical Education and Sports at Bingöl University (in Turkey) during the 2019-2020 academic year participated in the study as volunteers.

\subsection{Data Collection}

Demographic information form learned resourcefulness scale, academic procrastination scale, and were applied to the participants as a data collection tools. 


\subsubsection{Demographic Information Form}

The gender, age, grade point average (GPA), department, and grade information of the participants were given below (Table 1).

Table 1. Descriptive statistics of the participants

\begin{tabular}{cccc}
\hline Variables & Categories & $\mathrm{N}$ & $\%$ \\
\hline \multirow{2}{*}{ Gender } & Male & 270 & 72.6 \\
& Female & 102 & 27.4 \\
\hline \multirow{3}{*}{ Age } & $18-21$ & 217 & 58.3 \\
& $22-25$ & 142 & 38.2 \\
& 26 and older & 13 & 3.5 \\
\hline \multirow{3}{*}{ GPA } & $1.25-1.99$ & 29 & 7.8 \\
& $2.00-2.99$ & 268 & 72.0 \\
& $3.00-4.00$ & 75 & 20.2 \\
\hline \multirow{3}{*}{ Department } & Physical Education and Sports Teaching & 127 & 34.1 \\
& Coaching Training & 118 & 31.8 \\
& Sport Management & 127 & 34.1 \\
\hline \multirow{3}{*}{ Grade } & $1^{\text {st }}$ Grade & 54 & 14.5 \\
& $2^{\text {nd }}$ Grade & 218 & 58.6 \\
& $3^{\text {rd }}$ Grade & 100 & 26.9 \\
\hline
\end{tabular}

When Table 1 was examined, it was observed that $72.6 \%$ of the participants were male and $27.4 \%$ of them were female, $58.3 \%$ of them were in the age group of $18-21,38.2 \%$ of them were between $22-25$ years old, $3.5 \%$ of them were 26 years and older, the GPA of $7.8 \%$ was $1.25-1.99,2.00-2.99$ for $72.0 \%$, and $3.00-4.00$ for $20.2 \%, 34.1 \%$ of them were in the department of physical education and sports teaching, $31.7 \%$ of them were in coaching training, $34.1 \%$ of them were in sport management, and finally, $14.5 \%$ of them were in the first grade, $58.6 \%$ of them were in the second grade, and $26.9 \%$ of them were in third grade.

\subsubsection{Rosenbaum Learned Resourcefulness Scale}

This scale was developed by Rosenbaum (1983) and adapted to Turkish by Siva (1991). The scale was a 36-items and 5-point Likert-type ( $1=$ Never Defines, $5=$ Defines Very Well) and one-dimension. According to the response of the individual, each item gets from 1 to 5 points and gets a total score formed by adding them. Thus, a total score between 36 and 180 was obtained from the scale. High scores from the scale indicate the high self-control skills, so the coping strategies represented on the scale were often used. The Cronbach alpha reliability coefficient calculated to test the reliability of the original scale was found as .78. In the current study, this coefficient was found to be .74 .

\subsubsection{Aitken Academic Procrastination Scale}

This scale was developed by Aitken (1982) in order to measure the tendency of students to procrastination academic tasks and adapted to Turkish by Balkıs (2007). The scale was a 16-item and a 5-point Likert-type (1= Totally Wrong, $5=$ Completely Correct) and one-dimension. The score range in the scale was $16-80$. High scores indicate that individuals have a tendency to procrastination. The Cronbach alpha reliability coefficient calculated to test the reliability of the original scale was found as .89 . In the current study, this coefficient was found to be .80 .

\subsection{Data Analysis}

In analysis of the obtained data, IBM SPSS 24 (Statistical Package for the Social Sciences) package program was used. It was determined that the Skewness and Kurtosis values of the scales were between -1 and +1 (Table 2). The fact that these values were in the range of -1 and +1 were interpreted as not having excessive deviations from normality (Büyüköztürk, 2007). In this context, it was accepted that the data show normal distribution. In the study, Pearson Correlation analysis was used to reveal the relationship between the scores obtained from the scales, and Linear Regression analysis were used to determine whether the scores obtained were predicted each other. 
Table 2. The skewness and kurtosis values of the scale scores

\begin{tabular}{cccc}
\hline Variables & $\mathrm{N}$ & Skewness & Kurtosis \\
\hline Learned Resourcefulness & 372 & .229 & -.129 \\
Academic Procrastination & 372 & .067 & .987 \\
\hline
\end{tabular}

\section{Results}

In this section, the students' learned resourcefulness and academic procrastination score averages, the relationship between them and the details of the results based on the impact were presented in the Table 3, 4, 5 .

Table 3. The descriptive statistics of scores from the learned resourcefulness and academic procrastination

\begin{tabular}{ccccc}
\hline Variables & $\mathrm{n}$ & Min & Max & $\overline{\mathrm{X}} \pm \mathrm{SD}$ \\
\hline Learned Resourcefulness & 372 & 87.00 & 161.00 & $121.03 \pm 14.56$ \\
Academic Procrastination & 372 & 24.00 & 63.00 & $41.80 \pm 5.85$ \\
\hline
\end{tabular}

When Table 3 was examined, it was determined that the learned resourcefulness of the students was $121.03 \pm 14.56$ and their average from the academic procrastination scale was $41.80 \pm 5.85$.

Table 4. Pearson correlation analysis on learned resourcefulness and academic procrastination

\begin{tabular}{cccc}
\hline Variables & & $(1)$ & $(2)$ \\
\hline \multirow{2}{*}{ Learned Resourcefulness (1) } & $\mathrm{r}$ & 1 & \\
\cline { 2 - 4 } & $\mathrm{p}$ & & \\
\hline \multirow{2}{*}{ Academic Procrastination(2) } & $\mathrm{r}$ & $.287^{* *}$ & 1 \\
\cline { 2 - 4 } & $\mathrm{p}$ & .000 & \\
\hline $\mathrm{N}=372 ; * * \mathrm{p}<.01$ & & & \\
\hline
\end{tabular}

When Table 4 was analyzed, it was determined that there was a positive significant relationship between the learned resourcefulness and academic procrastination level $(\mathrm{p}<.01)$.

Table 5. Linear regression analysis on learned resourcefulness and academic procrastination

\begin{tabular}{cccccc}
\hline \multicolumn{7}{c}{ Dependent variable: Academic Procrastination } \\
\hline Variables & $\mathrm{B}$ & Standard Error & $\beta$ & $\mathrm{t}$ & $\mathrm{p}$ \\
\hline (Constant) & 91.226 & 5.231 & & 17.438 & .000 \\
Learned Resourcefulness & .713 & .124 & .287 & 5.754 & .000 \\
\hline \multicolumn{7}{c}{} \\
\hline \multicolumn{7}{c}{$\mathrm{R}^{2}=.082 ;$ adj. $\mathrm{R}^{2}=.080$} \\
$\mathrm{~F}=33.108 ; \mathrm{p}<.01$ \\
\hline
\end{tabular}

As a result of the analysis, it was found that learned resourcefulness predicted the academic procrastination variable by $8 \%\left(\mathrm{R}^{2}=.082\right)$. In addition, it was found that learned resourcefulness positively affects the level of academic procrastination $(\beta=.287, \mathrm{p}<.01)$.

\section{Discussion and Conclusion}

In this study, which was conducted to reveal the learned resourcefulness levels and academic procrastination status of students studying in the sports departments, it was found that the average of the students' learned resourcefulness scale was $121.03 \pm 14.56$ and the average of the academic procrastination scale was $41.80 \pm 5.85$. When the literature was examined, in studies related to learned resourcefulness, in the study of Amanvermez (2015) on university students the average value was 118.93, in Çoşkun's (2007) study on high school students was 116.21, in Garipağaoğlu and Güloğlu's (2015) research on teacher candidates 122.75, in the research conducted by Y 1 ldırım and Ekinci (2005) on university students, it was found the average value of 120.07 in the study of Bilge and Pektaş (2004) on university students the average value found as 122.75. It was seen that the results obtained from the literature and the results obtained in this research were very close. Considering that the total score that can be obtained from the learned resourcefulness scale will vary between 36 and 180, it has been concluded that the 
learned resourcefulness levels of the participants were moderate and they can use the strategies to cope with the difficulties encountered.

When the scale scores of academic procrastination were analyzed, it was determined that the participants had moderate procrastination. In the literature research conducted on the scale average values of academic procrastination. Yıldırım (2015) on the university students, Çoşar's (2019) on the teacher candidates, and Demir (2018) on the high school students it was determined that the academic procrastination were moderate. The results obtained from the literature were paralleled with the results of this research. Stressful experiences faced by students during the adaptation process to university life may have negative effects on students. Some students were more diligent in tackling adaptation challenges, while others simply give up trying and blame themselves if they fail. Protecting from these effects, dealing with problems more effectively and adapting better were closely related to the skills of students (Kennett \& Keefer, 2006).

When the linear correlation and Pearson regression analyzes results made in the study were examined, it was determined that there was a positive significant relationship between the learned resourcefulness and academic procrastination level. Moreover, it was found that learned resourcefulness was predicting the academic procrastination variable by approximately $8 \%$ and learned resourcefulness was positively affecting academic procrastination. In the problems faced by individuals with learned resourcefulness, it was thought that the behaviors exhibited by individuals with high academic procrastination and attitudes were contrary situations. Individuals who have academic procrastination were quite inadequate in dealing with problems, but on the contrary, individuals with high learned resourcefulness have the power to deal with all kinds of problems. When the literature on these findings were examined, in his study on prospective teachers, Arikan (2016) reported that there was a low level of the significant relationship between learned difficulty levels and academic procrastination behaviors. In the study of Akgün and Ciarrochi (2003), the relationship between learned resourcefulness and academic stress experienced by students was examined and they concluded that learned resourcefulness was a protective factor against academic stress. In their work in Kennett and Keefer (2006), they found that the learned resourcefulness affects academic success. Similarly, in the study by Leung and He (2010) obtained a parallel result. Accordingly, it can be interpreted that students trust themselves about their ability to fulfill their academic duties successfully, they try to manage their time and learning environments more effectively and they were willing to make efforts to cope with unwanted situations (Gün, Turabik, \& Atanur-Baskan, 2019), it can also be concluded that a number of related planned activities tend to procrastination.

It was supported by researches that students with high learning resourcefulness were successful in dealing with the stress caused by the high expectations of parents. For this reason, it was important for students to protect themselves against stress, maintain their emotional and physical well-being, and indirectly improve their learned resourcefulness as they were important for academic success. Students who continue their university education can research more and reach information more easily thanks to the modern education system and developing technology, depending on the increase in learned resourcefulness, it can be thought that there will be an increase in academic procrastination levels.

\section{Suggestions}

Guidance services at universities can prepare studies and training programs to increase the learned resourcefulness for individuals. Academic members can improve themselves by participating in training on the effects of stress caused by academic or out-of-school problems on the student and how to deal with them. Learned resourcefulness may cause psychological vulnerability to university students. To eliminate this risk, students should be able to develop themselves, and progress in their careers should be provided. Considering that loneliness, avoidance, and anger are causes increased stress in humans, and individuals with an asocial lifestyle are more likely to experience academic procrastination, individuals can be more involved in social settings, problems experienced can be shared with others, and the level of learned resourcefulness can be increased by engaging in activities related to training to cope with stress.

\section{Limitations}

This study was limited to students studying at School of Physical Education and Sports, Bingöl University (in Turkey), during the higher education at the 2019-2020 academic year. In addition, this study was quantitative research and was limited to the variables of learned resourcefulness and academic procrastination.

\section{References}

Aitken, M. E. (1982). A personality profile of the college student procrastinator (Unpublished doctoral dissertation). University of Pittsburgh, Pittsburgh, USA. 
Akgun, S., \& Ciarrochi, J. (2003). Learned resourcefulness moderates the relationship between academic stress and academic performance. Educational Psychology, 23(3), 287-294. https://doi.org/10.26466/opus.557530

Akkaya, E. (2007). Academic procrastination among faculty of education students: The role of gender, age, academic achievement, perfectionism and depression (Unpublished master's thesis). Middle East Technical University, Ankara, Turkey.

Amani, M., \& Arbabi, M. M. (2020). The mediating role of academic self-regulation in the relationship between parenting dimensions and academic procrastination. International Journal of School Health, 7(2), 21-29.

Amanvermez, Y. (2015). Üniversite birinci sını ögrencilerinin üniversite yaşamına uyumlarının güvengenlik ve ögrenilmiş güçlülük düzeylerine göre yordanması (Yüksek lisans tezi). Ege Üniversitesi, İzmir, Turkey.

Arıkan, H. E. (2016). Öğretmen adaylarının öğrenilmiş güçlülük düzeyleri ile akademik erteleme eğilimleri arasindaki ilişsisinin incelenmesi (Yüksek lisans tezi). Cumhuriyet Üniversitesi, Sivas, Turkey.

Balkıs, M. (2006). Üniversite öğrencilerinin davranışlarındaki erteleme eğiliminin, karar verme tarzlart ile ilişkisi (Yayımlanmamış doktora tezi). Dokuz Eylül Üniversitesi, İzmir, Turkey.

Balkıs, M. (2007). Üniversite adaylarının davranışlarındaki erteleme eğiliminin, karar verme stilleri ile ilişkisi. Pamukkale Üniversitesi Eğitim Fakültesi Dergisi, 21(1), 21-67.

Baydoğan, M., \& Dağ, İ. (2008). Hemodiyaliz hastalarındaki depresiflik düzeyinin yordanmasında kontrol odağı, öğrenilmiş güçlülük ve sosyotropi-otonomi. Türk Psikiyatri Dergisi, 19(1), 19-28.

Bilge, A., \& Pektaş, İ. (2004). Öğrencilerin Soysokültürel Özellikleri, Durumluk-Sürekli Kaygı Düzeyleri ve Başa Çıkma Becerilerinin İncelenmesi. Ege Üniversitesi Hemşirelik Yüksekokulu Dergisi, 20(1), 47-55.

Bilgili, H., \& Tekin, E. (2019). Örgütsel stres, örgütsel bağlllık ve öğrenilmiş güçlülük ilişkisi üzerine bir araştırma. Opus Uluslararası Toplum Araştırmalarl Dergisi, 11(18), 2165-2200. https://doi.org/10.26466/opus.557530

Büyüköztürk, Ş. (2007). Sosyal bilimler için veri analizi el kitabı (7. Baskı), Ankara: Pegem Akademi Yayıncılık.

Coşar, H. A. (2019). Öğretmen adaylarının sosyal medya bă̆ımlılığı ve akademik erteleme davranışları arasindaki ilişkinin incelenmesi (Yüksek lisans tezi). Aksaray Üniversites, Aksaray, Turkey.

Coşkun, Y. (2013). Lise öğrencilerinde öğrenilmiş güçlülük ve kontrol odaği algilama düzeyi ilişkisinin incelenmesi. Marmara University Atatürk Education Faculty Journal of Educational Sciences, 25(25), 71-85. Retrieved from https://dergipark.org.tr/tr/pub/maruaebd/issue/353/2501

Demir, M. F. (2018). Lise son sınıf ögrencilerinin üstbiliş becerileri ve akademik erteleme davranışları arasındaki ilişsinin incelenmesi (Yayınlanmamış yüksek lisans tezi). Kırşehir Ahi Evran Üniversitesi, Kırşehir, Turkey.

Dike, I., \& Emmanuel, S. O. (2019). Study on conscientiousness, academic self-efficacy and self-esteem predictive power on academic procrastination among counselling students. Psychocentrum Review, 1(2), 69-78. https://doi.org/10.30998/pcr.1281

Dönmez, B., \& Genç, G. (2006). Genel liselerdeki okul yöneticisi ve öğretmenlerin öğrenilmiş güçlülük düzeylerine ilişkin algıları. İnönü Üniversitesi Eğitim Fakültesi Dergisi, 7(12), 41-60.

Ferrari, J. R. (1991). Self-handicapping by procrastinators: protecting self-esteem, social esteem or both. Journal of research in personality, 25(3), 245-261. https://doi.org/10.1016/0092-6566(91)90018-L

Ferrari, J. R., \& Beck, B. (1999). Affective responses before and after fraudulent excuses by academic procrastinators. Education, 118, 529-537.

Garipağaoğlu, B. Ç., \& Güloğlu, B. (2015). Öğretmen adaylarında öz liderlik becerilerinin yordayıcısı olarak öğrenilmiş güçlülük ve denetim odağı. Abant İzzet Baysal Üniversitesi Eğitim Fakültesi Dergisi, 15(2), 147-162. 10.17240/aibuefd.2015.15.2-5000161317

Gün, F., Turabik, T., \& Atanur-Baskan, G. (2019). The relationship between academic self-efficacy and academic procrastination tendency: A study on teacher candidates. Hacettepe University Journal of Education. Advance online publication. https://doi.org/10.16986/HUJE.2019051688

Johnson, E. M., Green, K. E., \& Kluever, R. C. (2000). Psychometric characteristics of the revised procrastination inventory. Research in Higher Education, 41(2), 269-279. https://doi.org/10.1023/A:1007051423054 
Kandemir, M. (2010). Akademik erteleme davranışını açıklayıcı bir model (Yayınlanmamış yüksek lisans tezi). Gazi Üniversitesi, Ankara, Turkey.

Karasar, N. (2004). Bilimsel araştırma yöntemi. Ankara: Nobel Yayıncılık.

Kennett, D. J., \& Keefer, K. (2006). Impact of learned resourcefulness and theories of intelligence on academic achievement of university students: An integrated approach. Educational Psychology, 26(3), 441-457. https://doi.org/10.1080/01443410500342062

Kennett, D. J., Quinn-Nilas, C., \& Carty, T. (2020). The indirect effects of academic stress on student outcomes through resourcefulness and perceived control of stress. Studies in Higher Education, 1-13. https://doi.org/10.1080/03075079.2020.1723532

Koç, K. (2018). Beden eğitimi ve spor öğretmenliği adaylarının liderlik özellikleri ile sosyal problem çözme becerileri arasındaki ilişkinin incelenmesi. Spor Bilimleri Araştırmaları Dergisi, 3(2), 223-232. https://doi.org/10.25307/jssr.480730

Leung, G. S. M., \& He, X. (2010). Resourcefulness: A protective factor buffer against the academic stress of school aged children. Educational Psychology, 30(4), 395-410. https://doi.org/10.1080/01443411003682574

Muliani, R., Imam, H., \& Dendiawan, E. (2020). Relationship between stress level and academic procrastination among new nursing students. The Malaysian Journal of Nursing, 11(3), 63-67. https://doi.org10.31674/mjn.2020.v11i03.010

Newsome, L., Helou, M., \& Crismon, C. (2019). Cross-cultural study of students' response to education dissatisfaction: An Australian context. International Journal of Educational Studies, 2, 44-52. https://doi.org/10.22158/jecs.v2n4p315

Piza, F., Kesselheim, J. C., Perzhinsky, J., Drowos, J., Gillis, R., Moscovici, K., Danciu, T. E., Kosowska, A., \& Gooding, H. (2019). Awareness and usage of evidence-based learning strategies among health professions students and faculty. Medical teacher, 4l(12), 1411-1418. https://doi.org/10.1080/0142159X.2019.1645950

Rosenbaum, M. (1983). Learned resourcefulness as a behavioral repertoire for the self-regulation of internal events: Issues and speculations. Perspectives on Behavior Therapy in the Eighties, 9, 54-73.

Rosenbaum, M. (1990). The role of learned resourcefulness in the self-control of health behavior. New York: Springer Publishing.

Senécal, C., Koestner, R., \& Vallerand, R. J. (1995). Self-regulation and academic procrastination. Journal of Social Psychology, 135(1), 607-619. https://doi.org/10.1080/00224545.1995.9712234

Siva, A. N. (1991). Infertilitede stresle baş etme, öğrenilmiş güçlülük ve depresyonun incelenmesi (Yayımlanmamış doktora tezi). Hacettepe Üniversitesi, Ankara, Turkey.

Turan, M. B., Karaoğlu, B., \& Pepe, O. (2017). Relationship between academic procrastination, academic forgeries and success tendencies of the university students. Ankara: Gece Kitaplığı, Chapter 38, 1548.

Vural, B. (2004). Öğrenci başarısı için okul aile birliği (2. Baskı), İstanbul: Hayat yayıncılık.

Yıldırım, A., \& Ekinci, M. (2005). Eğitimi hemşirelik olan ve olmayan üniversite öğrencilerinin stresle başa çıkma düzeylerinin karşılaştırılması. Atatürk Üniversitesi Hemşirelik Yüksekokulu Dergisi, 8(3), 19-29.

Yıldırım, S. (2017). Üniversite öğrencilerinin akademik başarı, akademik erteleme, kopya çekme ve devamsızlı durumlarının yordayıcısı olarak sosyal bağglılık (Yüksek lisans tezi). Gaziosmanpaşa Üniversitesi, Tokat, Turkey.

Zauszniewski, J. A., \& Martın, M. H. (1999). Developmental task achievement and learned resourcefulness in healthy older adults. Archives of Psychiatric Nursing, 13(1), 41-47. https://doi.org/10.1016/S0883-9417(99)80016-8

\section{Copyrights}

Copyright for this article is retained by the author(s), with first publication rights granted to the journal.

This is an open-access article distributed under the terms and conditions of the Creative Commons Attribution license (http://creativecommons.org/licenses/by/4.0/). 